DOI: http://doi.org/10.21698/simi.2017.0019

\title{
GENERAL SCHEME TO EVALUATE THE DANGEROUSNESS OF WASTES IN ORDER TO MANAGE THEM BY PRODUCER/HOLDER ORGANIZATIONS
}

Georgeta Madalina Arama, Lidia Kim, Doina Guta

National Research and Development Institute for Industrial Ecology ECOIND, 71-73 Drumul Podul Dambovitei, 060652, Bucharest, Romania, madalina.arama@incdecoind.ro

\begin{abstract}
A general scheme for the assessment of dangerousness of waste is presented taking into consideration the new European and Romanian applicable laws in order to adequately manage them (storage, elimination with specialized firms - preparation for disposal/recovery, recovery, and final disposal). Some relevant examples from current practice will be reviewed emphasizing the interest aspects in applying the current legal provisions in order to adequately manage the waste in Romania in the spirit of sustainable development and protection of environment and human health on short, medium and long term.
\end{abstract}

Keywords: dangerousness, disposal, elimination, recovery, wastes

\section{Introduction}

The paper presents a general scheme for waste assessment based on current environmental and waste legislation as a methodological approach to be used in practice in order to make an appropriate waste management. Following economic development, our modern society is facing increasing amounts of wastes and consequently there is a strong necessity to adequately manage them in the spirit of sustainable development. In this respect, nowadays, any developed wastes' policies and strategies should be conceived in order to find balance between continuing economic development on one hand and decreasing natural resources consumption and wastes production in order to minimize their environment and human health negative effects on the other hand.

\section{Materials and methods}

The following assessment scheme presented in Figure 1 is based on the current environmental protection laws dedicated to the waste management. Waste, as is defined by legislation (Directive 2008/98/EC) is "any substance or object which the holder discards or intends or is required to discard". This legislation states that any waste assessment "should be based, inter alia on the Community legislation on chemicals, in particular concerning the classification of preparations as hazardous, including concentration limit values used for that purpose. Hazardous waste should be regulated under strict specifications in order to prevent or limit, as far as possible, the potential negative effects on the environment and on human health due to inappropriate management". European legislation states also that classification of any waste should be realized in accordance with the waste types list "as last established by Commission Decision 2000/532/EC in order to encourage a harmonized classification of them and ensure also the harmonized determination of hazardous 


\section{INTERNATIONAL SYMPOSIUM "THE ENVIRONMENT AND THE INDUSTRY", SIMI 2017, PROCEEDINGS BOOK}

waste within the European Union and adequate management"'(Commission Decision 2000/532/EC).

Activities involved in the appropriate waste management are referring to the sorting, collection, and preliminary storage of waste pending its further collection, transport, recovery/disposal treatment and disposal. The Directive 2008/98/EC for waste at Chapter I, Article 2 (1) presents also exceptions from its scope. The proposed scheme is transposing and summarizing the current waste law requirements. It has been conceived in order to help waste management taking into account the large variety of the generated waste. The classification of waste as hazardous should be based on a series of dangerous properties presented in Annex of Regulation nr 1357/2014 and also considering the Regulation (EC) No 1272/2008. The Romanian transposing Waste European Legislation is as follows: Law nr. 211/2011 (republished) regarding the waste regime, modified through the Governmental Order nr.68/2016 in force from 28 of October 2016, Commission Decision 2014/955/UE, for the modification of Decision 2000/532/CE to establish a waste list (the European Waste Catalogue), EU Regulation nr.1357/2014 replacing Annex III to Directive 2008/98/EC of the European Parliament and of the Council on waste and repealing certain Directives. The EU Regulation nr.1272/2008 gives explanations of the legally used concepts in assessing "hazardous substances and mixtures and specify the hazard classes". A substance or a mixture fulfilling the criteria relating to physical hazards, health hazards or environmental hazards, laid down in Parts 2 to 5 of Annex I is hazardous and shall be classified in relation to the respective hazard classes provided for in that Annex, where, in Annex I, hazard classes are differentiated on the basis of the route of exposure or the nature of the effects, the substance or mixture shall be classified in accordance with such differentiation". "

"A substance" means a chemical element and its compounds in the natural state or obtained by any manufacturing process".

Note 1: For waste classification purpose, the number from Chemical Abstract Services (English Abbreviation CAS nr.) for the corresponding element/compound/substance is recommended to be known so that, properties of interest can be verified.

"A 'mixture" means a mixture or solution composed of two or more substances".

Note 2: In the context of waste classification we should mention that usually a nonhomogeneous system (mixture) of two or more substances is called a mixture and a homogeneous system (mixture) of two or more substances is usually called solution.

\section{Results and Discussion}

Any endeavour related to waste characterization means actually a less or more extensive case study that necessitates organizing documentation from the producer/holder, in order to evaluate it and to elaborate a sampling plan for analytical relevant determinations (indicators) and finally, to assess all available data and information based on the applicable current waste legislation. According to our proposed presented scheme the waste should first be tested for its origin. If the origin is not known the branch 1 of the scheme Fig. 1 should be followed. If the origin is known, we will follow the branch 2 of the scheme. Procedural cassette 2A instructs to check with the producer/holder for different documents related to the technological processes where the waste originated. Afterwards, the cassette $2 \mathrm{~B}$ is followed in order to check if that waste is subject to law exclusions stipulated in Directive 2008/98/EC; chapter I; art 2. If this is not the case, the procedural cassette 2D is followed. This 


\section{INTERNATIONAL SYMPOSIUM "THE ENVIRONMENT AND THE INDUSTRY", SIMI 2017, PROCEEDINGS BOOK}

cassette instructs to ask the waste producer/holder to provide a summary of documents for possible existing hazardous materials/substances eliciting the hazardous properties from Annex to the Regulation (EU) nr.1357/2014, in the context of mentioned current applicable waste laws. Then, assessment continues with the procedural cassette $2 \mathrm{E}$ that requires producer/holder to provide, where it is possible, MSDS (English abbreviation for Material Safety Data Sheets) or search online information for the material/substances that might be found in waste in the same or different physical state with reference to that existing in MSDS. Next, the procedural cassette $2 \mathrm{~F}$ is followed. It instructs to compute the concentrations of dangerous substances with corresponding codes that can impart to the waste dangerous properties according to Annex of Regulation (EC) nr.1357/2014 and Regulation (EC) No 1272/2008. Those computations can be done from data and information included in MSDS and also from the process mass balances information. Following the cassette $2 \mathrm{G}$ a selection of appropriate analytical tests that should be performed can be realized according to the intended ways for waste management (sorting and storage for transport and management with a specialized waste management firm, pre-treatment for transport, recovery or final disposal). An adequate qualitative and quantitative waste characterization strategy can be planned and applied. That means that, from all obtained data and information, the relevant hazardous elements/compounds and substances should be assessed from the point of view of their inter-phases partition/distribution in the waste batch sample. Depending on the waste physical state and waste general exhibited properties it is decided the way that sampling program should be done according to the in place applicable current sampling standards so that the sample will have relevance for the type of waste or at least for the batch of analyzed waste. In the current practice, we are receiving waste characterization applications from a large diversity of clients both producers and holders who are trying to manage the waste, having a variety of origins according to the current law requirements. Most frequently encountered waste that can be analyzed for determination of different indicators is that in solid form with more or less humidity and of different granularity. In such waste, general indicators that can be usually analyzed are the so-called aggregated properties indicators such as: $\mathrm{pH}$, humidity, suspended maters, dry solids, total organic carbon, total inorganic carbon, calorific power, elemental analysis, TPH, metals/heavy metals, leachable substances etc. All these indicators complement the MSDS specific information about the substances that can be finally found in each analyzed waste batch. The literature in the field related to the analytical balances determination in the waste analysis shows that an error of $10 \%$ in mass analytical balances is usually accepted knowing that in any analyzed waste, transformations can occur modifying not only the physical state of the entered substances but also their chemical forms. Complex compounds of heavy metal for instance, that are found more in the humidity of a waste sample, are the most frequent case of elements transferable from solid phase in soluble form depending on waste $\mathrm{pH}$. Analytic protocols allowing the user to gain appropriate knowledge of the organic and inorganic substances in a waste and to allow the determination of the properties for the regulatory or recovery purposes have been considered in order to improve the waste analytical determinations approach with a combination of quantitative/qualitative methods. Qualitative methods are usually applied for organic parameters. Global (aggregated) indicators determinations are another example that is used for characterization of parts of waste composition that remain undetermined. 


\section{INTERNATIONAL SYMPOSIUM "THE ENVIRONMENT AND THE INDUSTRY", SIMI 2017, PROCEEDINGS BOOK}

Another very important issue in the case of analyzing a waste is related to its inherent heterogeneities which are difficult to be managed in order to have relevant results. Volatile compounds are those that will always tend to go in the atmosphere depending on the storage temperature. The relative solubility of different substances can change over the time along with rheological properties (viscosities and redistributions of substances between solid or liquid phases of a waste). The literature in the field (Hennerbert et al. 2013) states that using the combined type of methods, depending on each specific case, "it is possible to quantify in essential lines the composition of the waste batch sample in the terms of specific substances" taking into consideration that when performing computation of the hazardous properties "the level of concentration that impact the waste classification as hazardous through the contained present substances, in legislation, varies in a range of $0.1-10 \%$ and at those concentrations the relative error of the semi-quantitative analysis seems to be reduced." Always the pre-assessment waste characterization phase is a work done in consultation with the client and within a multidisciplinary team of assessors and analysts. The quality assurance program in laboratory where those determinations are made is followed in order to have defendable results. (Pascu et al. 2015). The cassette $2 \mathrm{H}$ from the scheme requires to have a short but comprehensive documentation related to the waste - technological process, raw and intermediate materials that can be found in waste, process material mass balances, operation technological parameters influencing the waste properties on short term but also on medium and long term. However, because in practice we are facing a large variety of waste, very well illustrated by all the waste codes existing in the European harmonized list of waste, we are not able to analyze all types of listed waste. For those types of waste that cannot be analyzed through usually laboratory procedures, the information from the MSDS of commercial used products' help us to make an appropriate characterization.

In Table 1 and 2, two examples of waste characterizations are presented next. In the tables are presented only few components, as an example, of some of the commercial used products. The used commercial products in the processes from where the waste is coming from, are more numerous than those presented in the Table 1 and Table 2. In a usual Report of waste characterization offered to our clients, all the relevant components are taken into consideration and what is presented in Table 1 and Table 2 for only few commercial products and their components is replicated for all relevant entered products in the process and their components. Properties HP $1 \div$ HP15 that might impart to waste hazardous properties are considered and a resolution for each property is given according to the made computation for all the found components with hazardous statements and categories codes. The present legislation especially the Regulation 1357/2014 is very helpful in summarizing the algorithm for computation of concentrations of waste compounds that present hazardous statements and category codes that might impart to the waste the hazardous properties identified as HP $1 \div$ HP 15 . The computed concentrations of those compounds are checked against the prescribed cut-off-values of each of HP1 $\div$ HP15 properties. 


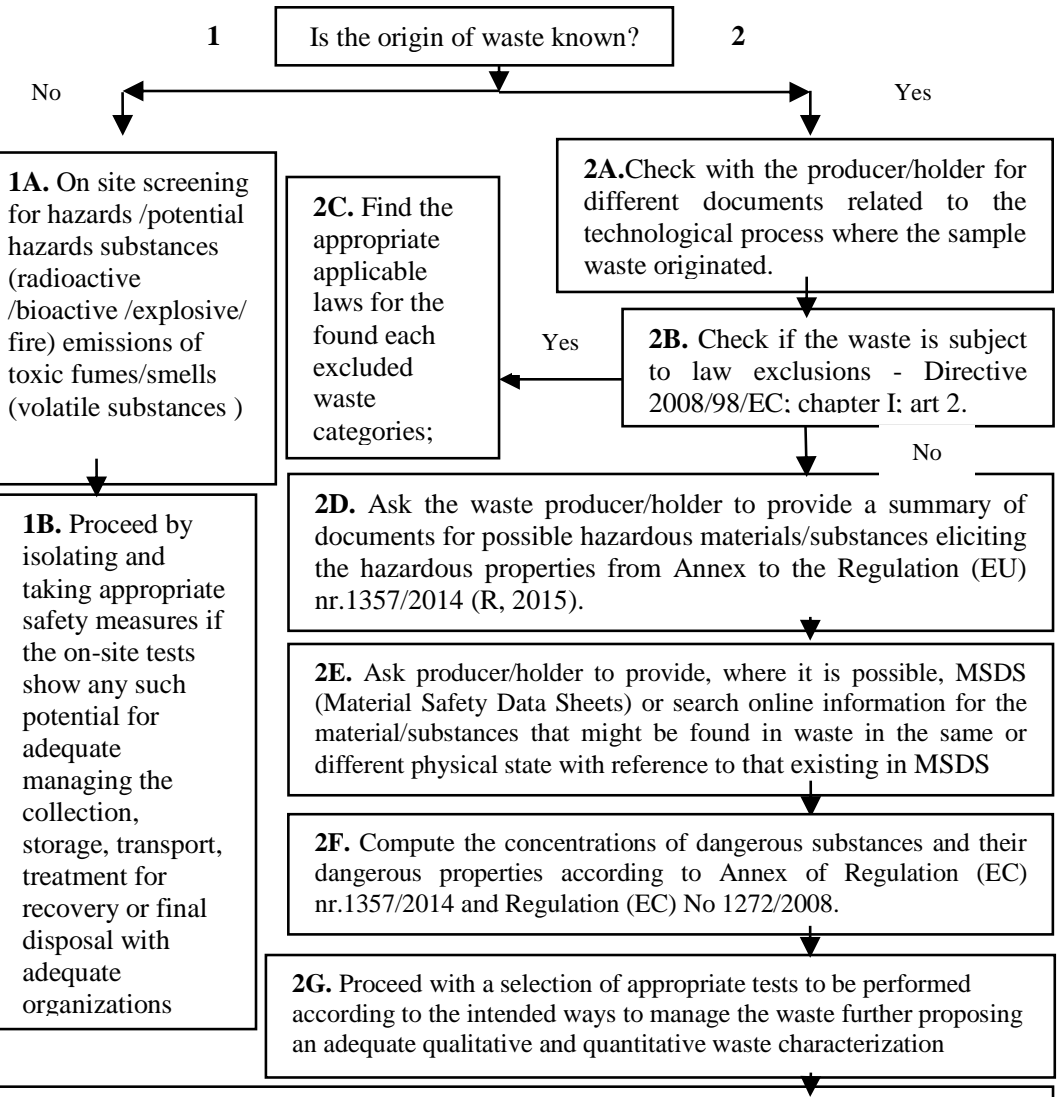

2H. Propose in consultation with the producer/holder the sampling plan/program, assuring that the analyzed sample is representative for the entire analyzed waste batch, knowing that waste are in general complex heterogeneous system with domains of nonhomogeneous properties that should be minimized as much as possible through adequate sampling program and laboratorv sample pretreatment.

2I. Depending on the obtained results for the general aggregated indicators $(\mathrm{pH}$, water content, dry solids, calorific power etc.) and specific indicators, a computation based on percentage determination of substances possessing hazardous properties based on MSDS, analytical tests, and a combination of both is performed reporting the results to the waste mass.

Figure 1. Scheme for waste assessment and classification

All existing or estimated substances to be found in wastes according to the entire available documentation and literature in the field, are screened and assessed for hazard statements and categories codes either in the presented MSDS or in the specialty literature according to the CAS number. Next, we give two examples of waste sediments coming from the physical-chemical step of treatment of the industrial 
waste washing waters, from two industries: car washing and food industries. Each of them contains detergent solutions. Both wastes have $\mathrm{pH}$ around 7 but have different humidity content. One waste has the humidity of approximately $30 \%$ and the sediment is mostly inorganic with only $2 \%$ TOC and the other one has the humidity of over $70 \%$ and has a greater organic content expressed as TOC of over $50 \%$. Both wastes have been analyzed from possible existing dangerous substances considering all useful information and data obtained from the waste producer/holder. The commercial used products' MSDS have been consulted in order to obtain for each component/substance the CAS nr. (English abbreviation for Chemical Abstract Services nr.). This allows to check for the hazardous statements and categories codes and also all other important physical properties such as concentration, solubility, flash temperature etc.).

\section{Conclusions}

The assessed waste according to the scheme Fig. 1 has been done in a methodical way following the legal requirements. The quantitative determination of assessed hazardous properties HP4 presented for two examples of waste from two industries have shown that the waste in the form that has been transmitted by our client has no hazardous properties imparted by the concentrations of the contained substances tested against legal cut off values. The greatest challenge in environmental toxicology is to understand the toxicity of mixture when different pollutants are coexisting and manifesting synergistic effects that is precisely why the topic of correct classification is one that should be given the necessary attention both in research studies and in practice. 
Table 1. Example 1 - Waste from washing and polishing cars activities

\begin{tabular}{|c|c|c|c|c|c|c|}
\hline \multirow[b]{2}{*}{$\begin{array}{c}\text { Commercial } \\
\text { product } \\
\text { type/Component of } \\
\text { the comercial } \\
\text { product identified } \\
\text { by CAS nr. }\end{array}$} & \multirow[b]{2}{*}{$\begin{array}{l}\text { Component } \\
\text { conc. in } \\
\text { commercial } \\
\text { product \% } \\
\text { (Min, Max ) }\end{array}$} & \multirow[b]{2}{*}{$\begin{array}{c}\text { Hazardous } \\
\text { statement - } \\
\text { Regulation nr. } \\
\text { 1357/3014 } \\
\text { (cut-off values) }\end{array}$} & \multirow[b]{2}{*}{$\begin{array}{c}\text { Waste Hazarous Property } \\
\text { (HP) according to } \\
\text { Regulation nr. 1357/2014 }\end{array}$} & Estimated compound in: & \multirow[b]{2}{*}{\begin{tabular}{|c|} 
Test $(\mathrm{c} 1+\mathrm{c} 2)$ \\
against cut - \\
off- values for \\
HP 4 - skin \\
irritant and eye \\
damage
\end{tabular}} & \multirow[b]{2}{*}{$\begin{array}{c}\text { Yes/No } \\
\text { hazardous waste } \\
\text { conclusions } \\
\text { according to } \\
\text { hazard statement }\end{array}$} \\
\hline & & & & $\begin{array}{l}\text { a)the monthly consumption } \\
\text { of comercial product (Kg } \\
\text { b) the humidity of the waste } \\
\text { sample (Kg) } \\
\text { c) waste, in weight }(\%)\end{array}$ & & \\
\hline $\begin{array}{c}\text { Liquid wax/Acetic } \\
\text { Acid (CAS 64-19-7) }\end{array}$ & $<0.25$ & $\begin{array}{l}\text { H314: } \\
\text { Skin corr } 1 \text { A } \\
\quad(\geq 1 \%)\end{array}$ & \multirow{2}{*}{$\begin{array}{l}\text { HP } 4 \text {,Irritant - skin irritant } \\
\text { and eye damage” waste which } \\
\text { on application can cause skin } \\
\text { irritation or dam age to the eye }\end{array}$} & $\begin{array}{l}\text { a1) } 0,011 \\
\text { b1) } 1,221.10^{-5} \\
\text { c1) } \mathbf{1 , 2 2 1 \times 1 0 ^ { - 6 }}\end{array}$ & \multirow{2}{*}{$\begin{array}{l}1.161 \times 10^{-3} \\
<1 \%\end{array}$} & \multirow{2}{*}{$\begin{array}{c}\text { No hazardous } \\
\text { waste }\end{array}$} \\
\hline $\begin{array}{l}\text { Car detergent/ } \\
\text { Sodium Hydroxide } \\
\text { (CAS 1310-73-2) }\end{array}$ & $(\geq 3,<5)$ & $\begin{array}{c}\text { H314: } \\
\text { Skin corr } 1 \mathrm{~A} \\
(\geq 1 \%)\end{array}$ & & $\begin{array}{l}\text { a2) } 10,5 \\
\text { b2) } 0.0116 \\
\text { c2) } \mathbf{1 , 1 6 \times 1 0 ^ { - 3 }}\end{array}$ & & \\
\hline
\end{tabular}

Table 2. Example 2 - Waste from washing equipments and hygiene activities from food industry

\begin{tabular}{|c|c|c|c|c|c|c|c|}
\hline \multirow{3}{*}{$\begin{array}{c}\text { Commercial } \\
\text { product type/ } \\
\text { Component of the } \\
\text { comercial product } \\
\text { identified by CAS } \\
\text { nr. }\end{array}$} & \multirow{3}{*}{$\begin{array}{l}\text { Component } \\
\text { conc. in } \\
\text { commercial } \\
\text { product \% } \\
\text { (Min, Max) }\end{array}$} & \multirow{3}{*}{\begin{tabular}{|c|} 
Hazardous \\
statement \\
Regulation \\
nr. \\
1357/3014 \\
(cut-off \\
values) \\
\end{tabular}} & \multirow{3}{*}{$\begin{array}{c}\text { Waste Hazarous } \\
\text { Property( HP) } \\
\text { according to } \\
\text { Regulation nr. } \\
1357 / 2014\end{array}$} & \multirow{3}{*}{\begin{tabular}{|c|} 
Analytically \\
determined \\
element conc. \\
/Estimated \\
associated \\
compound in \\
waste \\
\end{tabular}} & Estimated compound in: & \multirow{3}{*}{\begin{tabular}{|c|} 
Test $(\mathrm{c} 1+\mathrm{c} 2)$ \\
against cut - \\
off- values for \\
HP 4 - skin \\
irritant and eye \\
damage
\end{tabular}} & \multirow{3}{*}{$\begin{array}{c}\text { Yes/No } \\
\text { hazardous waste } \\
\text { conclusions } \\
\text { according to } \\
\text { hazard statement }\end{array}$} \\
\hline & & & & & \begin{tabular}{|c|} 
a) monthly consumption of \\
comercial product $(\mathrm{Kg})$
\end{tabular} & & \\
\hline & & & & & c) waste, in weight (\%) & & \\
\hline $\begin{array}{c}\text { Food detergent } \\
\text { /Sodium Hydroxide } \\
\text { (CAS 1310-73-2) }\end{array}$ & $(5,10)$ & $\begin{array}{c}\text { H314: } \\
\text { kin corr } 1 \mathrm{~A} \\
(\geq 1 \%)\end{array}$ & \multirow{2}{*}{$\begin{array}{c}\text { HP } 4 \text {,Irritant- } \\
\text { skin irritant and } \\
\text { eye damage” waste } \\
\text { which on } \\
\text { application can } \\
\text { cause skin irritation } \\
\text { or damage to the } \\
\text { eye }\end{array}$} & $\begin{array}{l}\text { Sodium } \\
/ \mathrm{NaOH}\end{array}$ & $\begin{array}{c}\text { a1) } 257 \\
\text { b1) } 59 \\
\text { c1) } \mathbf{1 . 0 3 \times 1 0 ^ { - 2 }}\end{array}$ & \multirow[b]{2}{*}{$\begin{array}{l}9,43 \times 10^{-2} \\
<1 \%\end{array}$} & \multirow[b]{2}{*}{$\begin{array}{c}\text { No hazardous } \\
\text { waste }\end{array}$} \\
\hline $\begin{array}{l}\text { Food detergent/- } \\
\text { Sodium } \\
\text { Hypochlorite (CAS } \\
7681-52-9)\end{array}$ & $(\leq 4)$ & $\begin{array}{c}\text { H314: } \\
\text { Skin corr 1 A } \\
(\geq 1 \%)\end{array}$ & & $\begin{array}{l}\text { Potassium } \\
\text { /KOH }\end{array}$ & $\begin{array}{l}\text { a2) } 254 \\
\text { b2) } 58 \\
\text { c2) } 8.40 \times 10^{-2}\end{array}$ & & \\
\hline
\end{tabular}




\section{References}

Anghel, A \& Criste, IV 2015, 'The transition of the quality management systems to the new requirements regarding the approach based on the risk assessment in the organization's processes', International Symposium "The Environment and The Industry", National Research and Development Institute for Industrial Ecology, Bucharest, pp 138-144.

Commission Decision 2000/532/EC of 3 May 2000 on hazardous waste, Official Journal L. 226, 06.09.2000.

Commission Decision 955 of 18 December 2014 amending Decision 2000/532/EC on the list of waste, Official Journal L. 370, 30.12.2014.

Directive 2008/98/EC of the European Parliament and of the Council of 19 November 2008 on waste and repealing certain Directives, Official Journal L. 312, 22.112008, pp 3-30. http://eur-lex.europa.eur/

Governmental Order no. 68 from 12 October 2016 for modification of Law211/2011 regarding the waste regime, Romanian Official Monitor no. 823, 18 October 2015

Law 211 2011, regarding the wastes regime; Romanian Official Monitor no. 837 from 25th November 2011.

Pascu, LF, Arama, GM \& Vasile GG 2015, Validation of analytical methods used in the environmental assessment studies, In: The necessity of validation of the methods used in monitoring pollutants and of the evaluation of the environmental pollution state practice - aspects of practical interest, Eds. Estfalia, Bucharest, pp 10-30 (in Romanian)

Pascu, LF \& Arama, GM 2015, Assurance of the results quality in laboratories for assays/tests through observing the harmonized requirements of the SR EN ISO/CEI 17025:2005 standard, In: Harmonized requirements of the measurement, control, monitoring and assessment of environmental pollution assessment activities at the European level, Eds. Estfalia, Bucharest, pp. 12-15. (Romanian)

Hennerbert, P, Papin, A, Padox, JM \& Hasebrouck, B 2013, 'The evaluation of analytical protocol for the determination of substances in waste for hazard identification', Waste Management, vol. 33, no. 7, pp 1577-1588.

Regulation (EU) No 1357/2014 of 18 December 2014 replacing Annex III to Directive 2008/98/EC of the European Parliament and of the Council on waste and repealing certain Directives O.J. L. 365, 19.12.2014.

Regulation (EC) No 1272/2008 of the European Parliament and of the Council of 16 December 2008 on classification, labeling and packaging of substances and mixtures, O.J. L. 353, 31.12.2008. http://eur-lex.europa.eu/ 